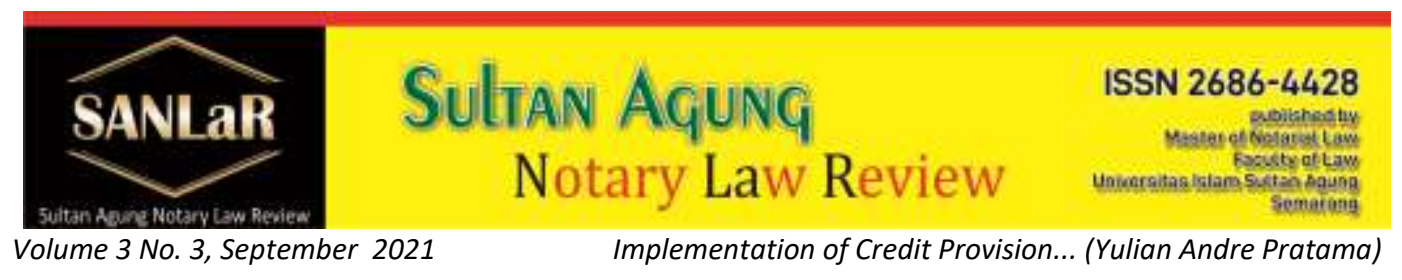

\title{
Implementation of Credit Provision at BRI (Bank Rakyat Indonesia) with Guaranteed Certificate
}

\author{
Yulian Andre Pratama*) \\ *) Faculty of Law, Universitas Islam Sultan Agung (UNISSULA) Semarang, E-mail: \\ yulianap2021@gmail.com
}

\begin{abstract}
The purpose of this study is to analyze 1). The process of granting credit to the BRI Unit Link Kajen Bank when the guarantee is still a transfer of rights. 2) Obstacles and solutions in the process of granting credit to the BRI Unit Link Kajen Bank when the guarantee is still a transfer of rights. This study uses a sociological juridical approach. The data used are primary and secondary data obtained through interviews and literature study, data analysis is descriptive analytic. The results of the research concluded: 1) The process of granting credit to the BRI Unit Link Kajen Bank at the time of the guarantee there was still a transfer of rights, namely submission of applications, submission of complete documents accompanied by photocopies of the documents for submitting the transfer of property rights to the Land Office, Examination, Analysis of memorandums, approval from branch leadership, execution and disbursement of loans by the Bank to debtors. The process of granting credit to the BRI Unit Link Kajen Bank is carried out by making a written agreement so that it is binding for the parties and becomes a strong evidence base if one day there is a dispute. 2. Constraints and solutions in the process of granting credit to the BRI Unit Link Kajen Bank at the time of the guarantee there was still a transfer of rights, namely the frequent delays in the delivery of notary orders so that the Notary did not have time to check administrative completeness or confirm to BPN due to limited time. Another obstacle is the difficulty of managing the time so that the signing of the deed can be signed together. The solution that can be done is to provide counseling to the bank about the order procedure carried out to a notary and provide understanding to the bank so that the files that have been submitted to the notary have actually been approved by the prospective debtor, both interest and administrative and insurance costs.
\end{abstract}

Keywords: Credit; Bank; Guarantee; Certificate; Transfer; Rights. 


\section{Introduction}

Banking is the target of economic development, where banks are expected to be able to develop and advance the economy in Indonesia. Especially in increasing the distribution of the welfare of the people at large, in this case it is not only the welfare of a group of people or individuals but the welfare of all Indonesian people without exception. This indicates that the bank is very important in national development because the function of the bank in Article 1 number 2 of the Act No. 10 of 1998 concerning Amendments to Act No. 7 of 1992 concerning Banking defines the function of a bank as a business entity that collects funds from the public. in the form of savings and distribute them to the public in the form of credit and or other forms in order to improve the standard of living of the people at large. ${ }^{1}$

Banking provides opportunities for the public to participate in development by raising funds through banking-run businesses, such as savings, deposits, and credit. The existence of savings, deposits, and credit causes the circulation of money in the community so that it can be used for development. To achieve these aims and objectives, the Limited Liability Company of Rural Banks carries out the following activities: ${ }^{2}$

a. Collecting funds from the public in the form of savings and time deposits,

b. Providing credit and providing guidance, especially to entrepreneurs from economically weak groups,

c. Cooperating between Rural Banks and with other Banking Institutions or Financial Institutions,

d. Carry out other banking businesses, as long as they do not conflict with the prevailing laws and regulations.

Credit provision services are indeed offered by all banks in Indonesia, but what is widely known by the wider community are banks whose branches are in all corners of the region in Indonesia, for example, business credit services offered by Bank Rakyat Indonesia (BRI) have helped the economy a lot the lower middle class, especially in terms of providing capital for businesses. However, the public should also be aware that in using bank services, especially in terms of taking business credit, there is a legal relationship that regulates the rights and

\footnotetext{
${ }^{1}$ Widjanarta, 1993, Hukum \& Ketentuan Perbankan di Indonesia, Pustaka Utama Grafiti, Jakarta, p. 204.

${ }^{2}$ Eric Compton, 1998, Dasar-dasar Perbankan, Translated by Alexander Ocy. Akademi Presindo, Jakarta, p. 7.
} 
obligations of debtors. This legal relationship is caused by an agreement that has been agreed by the bank as the creditor and the debtor as the consumer concerned.

In this case, we can see that there is a fairly clear difference between the agreement we are familiar with in general and the adhesion contract set by the bank. Capital is one of the factors of production in agriculture in addition to land, labor and management. The discussion of capital in agriculture cannot be separated from the discussion of credit issues in agriculture, which is one of the tools to help create capital. Bank Rakyat Indonesia (BRI) is a financial institution that provides financing to farmers, such as KUR and KKP-E, which are micro-scale bank credit products specifically for financing the agricultural sector. The vision of BRI Branch Kajen is to become a leading commercial bank that always prioritizes customer satisfaction. As a step towards realizing his vision, one of BRI's missions is to provide excellent service to customers through a wide-spread network and supported by professional human resources by implementing good corporate governance practices. Credit is the main source of income for banks and at the same time the largest source of operations, most of the operational funds are played in credit. If these activities are successful, the bank's business will be successful. However, if many banks are entangled in non-performing loans, this will have a major impact on bank operations. Credit is the main source of income for banks and at the same time the largest source of operations, most of the operational funds are played in credit. If these activities are successful, the bank's business will be successful. However, if many banks are entangled in nonperforming loans, this will have a major impact on bank operations. Credit is the main source of income for banks and at the same time the largest source of operations, most of the operational funds are played in credit. If these activities are successful, the bank's business will be successful. However, if many banks are entangled in non-performing loans, this will have a major impact on bank operations.

Agreements are generally made by both parties concerned with the aim of this agreement being mutually beneficial for both parties, while the adhesion contract imposed by the bank does not authorize the debtor to submit the desired conditions, because the agreement has been made previously by the banks and the debtor only have to agree or refuse to use banking services at the bank.

\section{Research Methods}

The approach method used in this study is a sociological juridical approach. Primary and secondary data sources obtained by interview method and literature review (study document). The data that has been collected both from 
field research and library research were analyzed using descriptive analysis methods.

\section{Results and Discussion}

3.1. Implementation of Credit Provisions at the BRI Bank Kajen Unit Link when the Guarantee is Still Occurring Transfer of Rights

Vision of PT. Bank Rakyat Indonesia (Persero) Tbk. Unit Link Kajen is to become a commercial bank leading which always prioritizes customer satisfaction with the mission of carrying out the best banking activities by prioritizing services to micro, small and medium enterprises to support the improvement of the community's economy, providing excellent service to customers through a wide spread network and supported by professional human resources and information technology reliable by implementing risk management and excellent Good Corporate Governance (GCG) practices, providing optimal benefits and benefits to interested parties (stakeholders). Based on the vision and mission of PT. Bank Rakyat Indonesia (Persero) Tbk.

To be able to make a guarantee agreement, the main agreement must be clearly regulated about the existence of promises regarding guarantees. With these promises as the source of the issuance of the guarantee agreement desired by the creditor and debtor. So making a guarantee agreement is one of the implementation of the main agreement. ${ }^{3}$

The credit binding process carried out by PT. Bank Rakyat Indonesia (BRI) (Persero) Tbk. Unit Link Kajen to debtors who use a certificate of ownership over land that is still in the process of transferring rights, namely:

1. The debtor submits an application

2. Debtors submit documents required by the Bank, such as:
a. Photocopy of Identity Card (ID)
b. Photocopy of Family Card (KK)
c. SK $80 \%$ and $100 \%$ (for $80 \%$ specifically for civil servants, but if private employees also have it, please include it)
d. NPWP (Taxpayer Identification Number)

\footnotetext{
${ }^{3}$ Ahmad Fauzi, Eksistensi Hak Tanggungan Dalam Kredit Perbankan, Jurnal Unpad, Bandung, p.51
} 
e. Photocopies of the documents for submitting the transfer of ownership rights to the Land Office, namely:

1) Application letter

2) Certificate

3) A photocopy of the statement of an Indonesian citizen, if the buyer is a foreigner who is legalized by the District Court

4) Permit for Transfer of Rights from the Head of the Land Office if the Transfer of Agricultural Land Rights

5) Attachment Letter of Deed according to the application (Sales and Purchases/Grants/ inheritance/Auction/Change of Name)

6) $S S B+S S P$

7) Photocopy of the last year's PBB that has been legalized

8) Certificate of inheritance and photocopy of ID of female experts

9) Death Certificate

10) Power of Attorney if the land is managed by another party (Stamped)

f. Savings book both at that bank and other banks

g. Certificate of place of work (for contract employees)

h. Salary slips for the last 3 (three) or 4 (four) months

i. A certificate of being able to pay credit installments properly if the retirement period is getting closer. For example, a working period of 10 years and 7 months and a prospective debtor wants to take a credit of 10 years, then a statement or guarantee from the leadership of the place of work is very necessary

3. Field inspection (survey) by an officer appointed by the Bank where the officer will check the cashflow of the debtor's business, the survey can be carried out more than once depending on the number of credit loans 
requested by the debtor. These officers are Account Officers, Marketing Management and Branch Managers if needed.

4. Memorandum analysis, namely to analyze the documents provided by the debtor with the conditions in the field using the prudential principle. The basic analysis used is legal, limit and leaning which are described in more detail to measure the feasibility of a prospective debtor's credit proposal. Legal seen from the validity and authenticity of various letters and administrative requirements submitted by a prospective debtor, such as the authenticity of the district head Certificate, KK, ID and others owned by the size of the credit platform proposed, banks usually apply a minimum of $40 \%$ of the value of the collateral they have. Leaning is a disbursement decision given to a customer after taking into account various other terms and conditions. This credit disbursement also pays attention to the possible risks that may arise in the future (future risk) because after all, banks must be very careful in the issue of credit disbursement.

\section{Approval from branch manager}

6. Execution is by asking the notary to make a credit agreement accompanied by a cover note from the notary. Cover note as a certificate or often termed as a closing note made by a notary. A cover note is issued by a Notary because the Notary has not finished his work in relation to his duties and authority to issue an authentic deed. The cover note is used to explain that the deed to be issued is still in progress and explain that the mortgage certificate is a formulation or prerequisite for the birth of a guarantee bond agreement from the loan disbursement agreement by the Bank, then the Bank can make credit disbursement ${ }^{4}$.

\section{Disbursement of loans by the Bank to debtors}

The process of binding credit with collateral for SHM land only lies in the cover note made by the Notary to the Bank as a promise by the Notary to immediately certify the land if the land is still in the process of transferring rights at the Land Office ${ }^{5}$.

\footnotetext{
${ }^{4}$ A Chuasanga, Ong Argo Victoria. (2019). Legal Principles Under Criminal Law in Indonesia \& Thailand, Jurnal Daulat Hukum, Vol 2, No 1 (2019)
} http://jurnal.unissula.ac.id/index.php/RH/article/view/4218 see Deen, Thaufiq., Ong Argo Victoria \& Sumain. (2018). Public Notary Services In Malaysia. JURNAL AKTA: Vol. 5, No. 4, 10171026. Retrieved from http://jurnal.unissula.ac.id/index.php/akta/article/view/4135

${ }^{5}$ Ong Argo Victoria, Ade Riusma Ariyana, Devina Arifani. (2020). Code of Ethics and Position of Notary in Indonesia. Sultan Agung Notary Law Review 2 (4), 397-407, http://lppmunissula.com/jurnal.unissula.ac.id/index.php/SANLaR/article/view/13536 see Yaya Kareng, Ong 
In agreement, the bank's customer credit must be able to provide certain objects that are linked as collateral. Guarantee law is a certain set that regulates or relates to guarantees in the context of accounts payable (loans of money) contained in various laws and regulations currently in force. Credit guarantees in credit agreements have several functions, namely: ${ }^{6}$

1. Credit guarantees as security for credit repayment.

2. Credit guarantees as a driver of debtor motivation.

3. Functions related to the implementation of banking.

The delivery of credit guarantees by the customer to the credit guarantee bank in the form of securities or in the form of goods (objects) so that it is a material guarantee and or in the form of a debt guarantee promise so that it is a material guarantee and or a debt guarantee promise so that it is an individual guarantee. Material guarantees entitle the holders of credit guarantees submitted by the borrower to generally be assessed before being accepted as objects of collateral for the loans provided. This banking assessment includes an assessment from a legal and economic point of view. ${ }^{7}$

The application for credit at the BRI Unit Link Kajen Bank with a guarantee to use land rights whose ownership status is still in the process of transferring rights at the Land Office must done by making a written agreement so that it is binding on the parties and becomes a strong basis of evidence if one day there is a dispute. This is emphasized in Article 10 of Act No. 4 of 1990 concerning Mortgage which states that in granting Mortgage, it is preceded by a promise to provide Mortgage as a guarantee for the repayment of certain debts, which is stated in and is an inseparable part of the debt agreement concerned or other agreements that give rise to the debt. The promise can be included in the Deed of Granting Mortgage Rights (APHT). The process of assigning Mortgage Rights to owned land which is still in the process of transferring rights at the Land Office is preceded by a promise to give Mortgage Rights as collateral for the Debtor in the main agreement and signed in the SKMHT together with the Debtor and Creditor before a Notary. After the SKHMT is registered, after that, the Deed of Mortgage Encumbrance (APHT) is made, no later than 1 month, as described in Article 15 of Act No. 4 of 1996 concerning Mortgage Rights.

The Deed of Granting Mortgage (APHT) must be in accordance with Article 11 paragraph (1) of Act No. 4 of 1996 concerning Mortgage Rights, the APHT contains promises that have been regulated in Article 11 paragraph (2) of Act

\footnotetext{
Argo Victoria, R. Juli Moertiyono. (2019). How Notary's Service in Thailand. Sultan Agung Notary Law Review, 1 (1), 46-56, http://jurnal.unissula.ac.id/index.php/SANLaR/article/view/4435

${ }^{6}$ M.Bahsan, 2007, Hukum Jaminan \& Jaminan Kredit Perbankan Indonesia, Raja Grafindo Persada, Jakarta, p. 103

${ }^{7}$ Ibid, p.3
} 
No. 4 of 1996 concerning Mortgage Rights, but the parties can make other promises as long as they do not conflict with the law, morality and public order. This is based on the principle of freedom of contract in contract law, this means giving freedom in such a way that everyone is entitled and free to make or enter into agreements containing whatever is in accordance with the will of the parties who promise, as long as it does not violate public order and morality. The promises contained in the APHT authorize the Mortgage holder to own the object of the Mortgage if the Debtor is in breach of contract. ${ }^{8}$

Rule law regarding the implementation of the imposition of Mortgage Rights in a credit agreement aims to provide legal certainty and protection for all parties in utilizing land and objects related to land as credit guarantees. For this reason, the practice of binding credit with mortgage guarantees in banking activities should also be carried out in accordance with what has been regulated in Act No. 4 of 1996 concerning Mortgage Rights. The purpose of the existence of Act No. 4 of 1996 concerning Mortgage Rights is intended to provide and provide balanced and good protection to credit recipients and credit lenders by treating them with strong guarantee rights institutions and providing legal certainty as well.

Credit grant to Debtors of a bank must also think about what is the maximum limit for granting credit that is considered appropriate or does not interfere with bank capital because the stability of banking capital is one of the important prerequisites for the operation of a bank. Bank Indonesia stipulates that it may not exceed $30 \%$ of the bank's capital and in accordance with the provisions of Article 11 paragraphs (1) and (2) of Act No. 10 of 1998 concerning Banking.

\subsection{Constraints and Solutions in the Process of Providing Credit at the} BRI Unit Link Kajen Bank when the Collateral Still Occurs Transfer of Rights

The implementation of the granting of credit between the Bank and the creditor must have a valid agreement or agreement named credit agreement. A credit agreement is an agreement between a debtor and a creditor (can be a bank) that creates a debt relationship, where the debtor is obliged to repay the loan given by the creditor, based on the terms and conditions agreed upon by both parties, the credit agreement is also called with a real principal agreement. ${ }^{9}$

\footnotetext{
${ }^{8}$ Yunita Krysna, Jaminan Hak Tanggungan Atas Tanah Milik Pihak Ketiga Dalam Perjanjian Kredit Di Lembaga Keuangan Perbankan Berdasarkan Undang - Undang Nomor 4 Tahun 1996 Tentang Hak Tanggungan, Jurnal Privat Law, Vol. IV No. 2 July - December 2016, p.147

${ }^{9}$ Dessy Andiyaningsih, Umar Ma'ruf, Pengalihan Hak Tanggungan Pada Perbankan di Kabupaten Banjarnegara, Jurnal Akta, Vol 5 No 1 March 2018, p.89
} 
Credit can be provided with collateral or without collateral. Unsecured loans are very dangerous for the bank's position, considering that if the customer experiences a traffic jam, it will be difficult to cover losses on the loans disbursed. On the other hand, with a credit guarantee, it is relatively safer considering that any bad credit will be covered by the guarantee. ${ }^{10}$

Collateral in the banking business is one of the efforts so that loans given to debtors are repaid in accordance with the agreed time period by obtaining results in the form of profits from the business. The recent reality, based on the mass media coverage and the existing literature, is that there are various obstacles in "taking" collateral to pay off debts in accordance with the debt agreement with the debtor and also the obstacles faced in the execution of the collateral. ${ }^{11}$

In granting credit, the bank must pay close attention to the process of granting credit. The process of granting credit is seen to find out where errors and deficiencies are, as well as look for when a problem occurs. The efforts of the bank in securing the disbursed funds are also very important, because it is to prevent the bank from suffering losses. In granting credit, the bank must also consider the obstacles that arise, because to anticipate that the bank (creditor) can choose the ways that must be taken so that it does not contain too much risk. $^{12}$

In the process of granting credit to the BRI Unit Link Kajen Bank, when the guarantee was still occurring, the transfer of rights encountered several obstacles, including:

1. Obstacles experienced by Notaries

Notary order letter from the bank which should have been received by the notary at least 1 day before the binding is held, so that the notary can check administrative completeness and confirm to the National Land Agency (BPN), but in practice it often happens that the file is received by the notary 2 hours before the credit agreement. This is certainly a big obstacle for the notary to check the completeness of the administration and confirm to the BPN because of the limited time.

2. Barriers experienced by the Bank

The Bank has difficulty in making an authentic deed before a Notary at the same time and place. The large number of notary duties causes the notary to

\footnotetext{
${ }^{10}$ Kasmir, 2014, Dasar-Dasar Perbankan, Raja Grafindo Persada, Jakarta, p.125

11 Marulak Pardede, Implementasi Jaminan Fidusia dalam Pemberian Kredit di Indonesia, Laporan Akhir Penelitian Hukum , Badan Pembinaan Hukum Nasional Departemen Hukum \& HAM RI, 2006, p.9

12 Lanang Galuh, Tinjauan Yuridis Tentang Pelaksanaan Perjanjian Kredit dengan Jaminan Fidusia, Naskah Publikasi, Universitas Muhammadiyah Surakarta, 2013, p.6
} 
be unable to serve the bank at all times in making the credit agreement deed. In practice, notaries sometimes send their employees to the bank to process the credit agreement deed. In addition, the busyness of bank directors causes them to be unable to enter into joint credit agreements with bank customers together in the presence of a notary. The signing of the credit agreement deed is sometimes done at a different time and place.

The possible solutions to these obstacles are:

1. Provide counseling to the bank about the order procedure carried out to a notary

2. Provide understanding to the bank so that the file that has been submitted to the notary has actually been approved by the prospective debtor, both interest and administrative and insurance costs, so that the agreement signed at a separate time does not cause errors in the future.

Banking is a financial institution that is the main pillar for accelerating national economic development, namely to support the implementation of national development in order to increase equity, economic growth and national stability towards increasing the welfare of the people at large. Bank services are very important in the economic development of a country, where the Bank is a financial institution capable of providing financial support for the development of the business world. The development of the business world will encourage economic growth, reduce unemployment and poverty in a country. As stated in Article 3 of Act No. 10 of 1998,

\section{Closing}

Based on the description above, the conclusions in this study are: 1) The process of granting credit to the BRI Unit Link Kajen Bank at the time of the guarantee there is still a transfer of rights, namely: The debtor submits an application, The debtor submits the documents required by the Bank, along with photocopies of the documents for submitting the transfer of ownership rights to the Land Office, Field inspection (survey) by officers, Memorandum analysis, which is to analyze the documents provided by the debtor with the conditions in the field using the prudential principle, Approval from branch manager, Execution, Disbursement of loans by the Bank to debtors, The process of granting credit to the BRI Unit Link Kajen Bank is carried out by making a written agreement so that it is binding for the parties and becomes a strong evidence base if one day there is a dispute. 2) Constraints and solutions in the process of granting credit to the BRI Unit Link Kajen Bank at the time of the guarantee there was still a transfer of rights, namely the frequent delays in the delivery of notary orders so that the Notary did not have time to check administrative completeness or confirm to BPN due to limited time. Another obstacle is the difficulty of managing the time so that the signing of the deed can be signed together. The solution that can be done is 
to provide counseling to the bank about the order procedure carried out to a notary and provide understanding to the bank so that the files that have been submitted to the notary have actually been approved by the prospective debtor, both interest and administrative and insurance costs.

\section{References}

Journals:

[1] A Chuasanga, Ong Argo Victoria. (2019). Legal Principles Under Criminal Law in Indonesia \& Thailand, Jurnal Daulat Hukum, Vol 2, No 1 (2019) http://jurnal.unissula.ac.id/index.php/RH/article/view/4218

[2] Ahmad Fauzi, Eksistensi Hak Tanggungan Dalam Kredit Perbankan, Jurnal Unpad, Bandung

[3] Deen, Thaufiq., Ong Argo Victoria \& Sumain. (2018). Public Notary Services In Malaysia. JURNAL AKTA: Vol. 5, No. 4, 1017-1026. Retrieved from http://jurnal.unissula.ac.id/index.php/akta/article/view/4135

[4] Dessy Andiyaningsih, Umar Ma'ruf, Pengalihan Hak Tanggungan Pada Perbankan di Kabupaten Banjarnegara, Jurnal Akta, Vol 5 No 1 March 2018

[5] Ong Argo Victoria, Ade Riusma Ariyana, Devina Arifani. (2020). Code of Ethics and Position of Notary in Indonesia. Sultan Agung Notary Law $\begin{array}{lllll}\text { Review } & 2 & \text { (4), 397-407, } \quad \text { http://lppm- }\end{array}$ unissula.com/jurnal.unissula.ac.id/index.php/SANLaR/article/view/13536

[6] Yaya Kareng, Ong Argo Victoria, R. Juli Moertiyono. (2019). How Notary's Service in Thailand. Sultan Agung Notary Law Review, 1 (1), 46-56, http://jurnal.unissula.ac.id/index.php/SANLaR/article/view/4435

[7] Yunita Krysna, Jaminan Hak Tanggungan Atas Tanah Milik Pihak Ketiga Dalam Perjanjian Kredit Di Lembaga Keuangan Perbankan Berdasarkan Undang - Undang Nomor 4 Tahun 1996 Tentang Hak Tanggungan, Jurnal Privat Law, Vol. IV No. 2 July - December 2016

Books:

[1] Achmad Ali, 2002, Menguak Tabir Hukum, Gunung Agung, Jakarta

[2] Adrian Sutedi, 2018, Peralihan Hak Atas Tanah \& Pendaftarannya, print.9, Sinar Grafika, Jakarta

[3] Akhmad Khisni, 2017, Hukum Waris Islam, print. IV, Unissula Press, Semarang

[4] Bambang Sunggono, 2006, Metode Penelitian Hukum ,Rajawali pers,Jakarta 
[5] Boedi Harsono, 2003, Menuju Penyempurnaan Hukum Tanah Nasional, cetakan kedua, Universitas Trisaksi, Jakarta

[6] Dyara Radhite Oryza Fea, 2018, Panduan Mengurus Tanah Rumah \& Perizinannya, Legality, Yogyakarta

[7] Eric Compton, 1998, Dasar-dasar Perbankan, Translated by Alexander Ocy. Akademi Presindo, Jakarta

[8] H. Juhaya S. Praja, Teori Hukum \& Aplikasinya,Bandung, CV Pustaka Setia, Cetakan kedua, 2014,

[9] Ismail, 2010, Manajemen Perbankan dari Teori Menuju Aplikasi, Kencana Perdana Media, Jakarta

[10] Kasmir, 2014, Dasar-Dasar Perbankan, Raja Grafindo Persada, Jakarta

[11] Kasmir, 2014, Dasar-Dasar Perbankan, Raja Grafindo Persada, Jakarta

[12] Lanang Galuh, Tinjauan Yuridis Tentang Pelaksanaan Perjanjian Kredit dengan Jaminan Fidusia, Naskah Publikasi, Universitas Muhammadiyah Surakarta, 2013

[13] M.Bahsan, 2007, Hukum Jaminan \& Jaminan Kredit Perbankan Indonesia, Raja Grafindo Persada, Jakarta

[14] Marulak Pardede, Implementasi Jaminan Fidusia dalam Pemberian Kredit di Indonesia, Laporan Akhir Penelitian Hukum , Badan Pembinaan Hukum Nasional Departemen Hukum \& HAM RI, 2006

[15] Widjanarta, 1993, Hukum \& Ketentuan Perbankan di Indonesia, Pustaka Utama Grafiti, Jakarta

Regulation:

[1] Act No. 10 of 1998 concerning Banking

[2] Act No. 2 of 2014 concerning Amendments to Act No. 30 of 2004 concerning the Position of Notary

[3] Act No. 4 of 1996 concerning Mortgage Rights

[4] Code of Civil law

[5] Constitution of the Republic of Indonesia1945

[6] Government Regulation of the Republic of Indonesia No.24 of 2007 concerning Land Registration 